\title{
Tolerance of crambe (Crambe abyssinica Hochst) to salinity and water stress during seed germination and initial seedling growth
}

\section{Tolerância do crambe (Crambe abyssinica Hochst) à salinidade e ao estresse hídrico durante a germinação das sementes e crescimento inicial das plântulas}

\author{
Martha Freire da Silva ${ }^{*}$ (D) , Eduardo Fontes Araújo1 (D), Laércio Junio da Silva1 (D), \\ Hugo Tiago Ribeiro Amaro ${ }^{2}$ (D), Luiz Antônio dos Santos Dias ${ }^{1}(\mathbb{D})$, Denise Cunha Fernandes dos Santos Dias ${ }^{1}$
}

${ }^{1}$ Universidade Federal de Viçosa/UFV, Departamento de Fitotecnia, Viçosa, MG, Brasil

2Universidade Estadual de Montes Claros/Unimontes, Departamento de Ciências Agrárias, Paracatu, MG, Brasil

*Corresponding author: marthafreire86@hotmail.com

Received in November 6, 2018 and approved in February 15, 2019

\begin{abstract}
Crambe is an oilseed plant whose oil is suitable for various industrial purposes, such as production of biodiesel, plastics, rubbers, and cosmetics. There are reports of the rusticity of this species and its potential for growth in arid and semi-arid environments, where water scarcity and soil salinity are common. However, studies regarding the tolerance of its seeds to these stresses and the physiological responses triggered during germination and seedling establishment under these conditions are incipient. The objective of this study was to evaluate the tolerance of crambe seeds to water deficit and salt stress during germination and early seedling development, as well as to investigate the role of antioxidant enzymes on tolerance to these conditions. The seeds were exposed to water and salt stresses and their performance was analyzed. Seed water content, imbibition rate, percentage and speed of germination, and the base water potential for seed germination were evaluated. In the seedlings, the following measurements were made: root and shoot length, fresh and dry matter of roots and shoots, moisture content, and activity of the enzymes superoxide dismutase (SOD), catalase (CAT), and peroxidase (POX). Water deficit and salt stress reduce the water uptake rate of the seeds, the germination and growth of seedlings. The crambe seeds had higher tolerance to salt stress than to water deficit. Absorption of salt and the action of the SOD and CAT antioxidant enzymes are part of the tolerance mechanisms of crambe seeds to salt stress.
\end{abstract}

Index terms: Abiotic stresses; antioxidant enzymes; polyethylene glycol; potassium chloride; oilseed plant.

\begin{abstract}
RESUMO
Crambe é uma oleaginosa adequada para vários fins industriais, como a produção de biodiesel, plásticos, borrachas e cosméticos. Há relatos da rusticidade desta espécie e seu potencial para o plantio em ambientes áridos e semi-áridos, onde a escassez de água e salinidade do solo são comuns. Entretanto, estudos sobre a tolerância de sementes a estes estresses e as respostas fisiológicas desencadeadas durante a germinação e estabelecimento de plântulas nessas condições são incipientes. O objetivo deste trabalho foi avaliar a tolerância de sementes de crambe ao déficit hídrico e ao estresse salino durante a germinação e desenvolvimento inicial de plântulas, bem como investigar o papel das enzimas antioxidantes na tolerância a essas condições. As sementes foram expostas aos estresses hídrico e salino e seu desempenho foi analisado. Avaliou-se o grau de umidade, taxa de embebição, porcentagem e velocidade de germinação e o potencial hídrico base para a germinação das sementes. Nas plântulas, as seguintes medidas foram realizadas: comprimento da raiz e parte aérea, massa fresca e seca da raiz e parte aérea, teor de água e atividade das enzimas superóxido dismutase (SOD), catalase (CAT) e peroxidase (POX). O déficit hídrico e o estresse salino reduzem a taxa de absorção de água das sementes, a germinação e o crescimento de plântulas. As sementes de crambe apresentam maior tolerância ao estresse salino do que ao déficit hídrico. A absorção do sal e a ação das enzimas antioxidantes SOD e CAT fazem parte do mecanismo de tolerância das sementes de crambe ao estresse salino.
\end{abstract}

Termos para indexação: Estresses abióticos; enzimas antioxidantes; polietileno glicol; cloreto de potássio; oleaginosa.

\section{INTRODUCTION}

Crambe (Crambe abyssinica Hochst) is an annual, short-cycle oilseed, belonging to the Brassicaceae family, which stands out for good yield and high oil content in its seeds. Seed oil content is about 36\%-38\% (Pitol; Broch;
Roscoe, 2010). It is a very promising crop for industrial uses; the oil from its seeds can be used in production of biofuels, biodegradable plastics, nylon, adhesives, electrical isolation, lubricants, anticorrosive agents, rubbers, and cosmetics (Falasca et al., 2010; Tavares et al., 2017). Furthermore, the bran produced in the oil extraction 
process can be used for animal feed (Falasca et al., 2010; Goes et al., 2018), and the leaves used in the preparation of nematicides (Coltro-Roncato et al., 2016).

There are reports of the rusticity of this species and its potential for growing in arid and semi-arid environments, where water scarcity and soil salinity are common (Ionov et al., 2013; Pivetta et al., 2016), which could make it an excellent crop alternative under these conditions.

Water and salt stresses are among the abiotic factors that most affect seed germination and plant development. It is estimated that $19.5 \%$ of the world's irrigated land (45 million hectares), and $2.1 \%$ of the non-irrigated land (about 32 million hectares) are affected by salinity (Oliveira; Gomes-Filho; Enéias-Filho, 2010), and these numbers grow every year. Thus, understanding seed responses to these stresses is important in the face of global climate change and increasing salinization of soils.

Water is essential for the germination process (Bewley et al., 2013). Under low soil osmotic potential, when water deficit occurs, seeds might not germinate. A similar effect can be observed in the presence of salts, which affect the water potential of the soil. This reduces the potential gradient between the soil and seed surface, restricting water uptake and, consequently, reducing germination rate. Under these stresses, plant establishment, as well as later plant development, may be compromised (Rengasamy, 2010), which makes cultivation in certain regions unfeasible. Salinity may also cause accumulation of intracellular ions, with a toxic effect. Ionic toxicity, during the germination process, causes several physiological and biochemical disorders, which contributes to loss of seed vigor (Yacoubi et al., 2013).

The osmotic and ionic effects of water deficit and salt stress can lead to an increase in the production of reactive oxygen species (ROS), which interact with several molecules, leading to lipid peroxidation, protein denaturation, membrane destruction, and mutation of DNA. In order to maintain cellular homeostasis, preventing oxidative damage, seeds activate the antioxidative defense system, which includes antioxidant enzymes. This defense system promotes control of the intracellular concentration of ROS (Kumar et al., 2015). The internal content of these compounds and the performance of the antioxidant defense system are strictly associated with success in seed germination (Gomes; Garcia, 2013), especially in situations of abiotic stresses and in salt stress relief in seedlings (Jabeen; Ahmad, 2013).

Studies that evaluate the tolerance of crambe to water and salt stresses and the physiological responses triggered in the seeds of this species during the germination and establishment of seedlings under these conditions are still incipient. This information is important to subsidize plant breeding programs aiming to develop genotypes more adapted to stress conditions. In addition, investigation of the level of stress tolerance can generate useful information in decision making regarding the productive process of this crop in relation to appropriate choice of the growing region, for example, according to rain availability, and adequate destination of the areas that have salinity problems. Therefore, it is necessary to investigate the tolerance level and investigate the physiological and biochemical responses to water and salt stresses during the germination of the seeds of this species. Thus, the objective of this study was to investigate the effects of water deficit and salt stress on water uptake, seed germination, and early development of crambe seedlings, as well as to investigate the role of antioxidative enzymes in seedlings under these conditions.

\section{MATERIAL AND METHODS}

This study was conducted at the Seed Research Laboratory of the Plant Science Department of the Universidade Federal de Viçosa, Minas Gerais, Brazil. Crambe seeds from the cultivar FMS Brilhante were used.

To simulate water deficit, polyethylene glycol 6000 (PEG 6000) solutions were prepared according to Villela, Doni Filho and Sequeira (1991). To simulate salt stress, potassium chloride $(\mathrm{KCl})$ solutions were prepared following the equation of Van 't Hoff (Salisbury; Ross, 1992), where $\Psi_{0}=$ osmotic potential (MPa), C = concentration $\left(\mathrm{mol} \mathrm{L}^{-1}\right), \mathrm{i}=$ isotonic coefficient, $\mathrm{R}=$ general gas constant $\left(0.0082 \mathrm{MPa} \mathrm{mol}^{-1} \mathrm{~K}^{-1}\right)$, and $\mathrm{T}=$ temperature $(\mathrm{K})$.

The PEG 6000 and $\mathrm{KCl}$ solutions were prepared at the following osmotic potentials: $0.0,-0.2,-0.4,-0.6$, and $-0.8 \mathrm{MPa}$. The zero-potential represented the control, without stress, for which distilled water was used. These osmotic potentials corresponded to the concentrations of 0 , $112.23,169.43,213.64$, and $251.03 \mathrm{~g} \mathrm{~L}^{-1}$ of PEG 6000 and $0,3.38,6.77,10.16$, and $13.55 \mathrm{~g} \mathrm{~L}^{-1}$ of $\mathrm{KCl}$, respectively, at the temperature of $25^{\circ} \mathrm{C}$.

Imbibition curves were obtained by successive weighing of four replicates of 50 seeds each. The initial water content of the seeds was previously determined by the drying oven method at $105^{\circ} \mathrm{C}$ for 24 hours (Brasil, 2009). The seeds were first weighed and then soaked between three sheets of paper towel, moistened with 10 $\mathrm{mL}$ of solution at the different potentials of PEG solutions, to simulate water stress, or $\mathrm{KCl}$ solutions, to simulate salt 
stress. Weights were recorded every two hours in the first 12 hours of imbibition and every 12 hours after that until $50 \%$ of the seeds exhibited radicle emergence or until the seventh day of treatment for seeds that did not show radicle emergence. The weights obtained were divided by the initial weight of the seeds, and these data were used to estimate the water uptake curves of the seeds, calculated by the Blacklow equation (1972): $\mathrm{W}=(\mathrm{a}+\mathrm{bt})-\left(\alpha-\mathrm{Wo}^{\prime}\right) / \exp$ $(\mathrm{kt})$, interpreted as follows: $W$ is the increase in seed weight in proportion to the initial weight; $\alpha$ is the asymptote when $\mathrm{t}=0$; $\mathrm{b}$ is the slope; $W_{o}$ 'is the adjusted initial weight; $k$ is the water uptake rate constant; and $t$ is the time.

During the imbibition process, the seeds were observed and photographed. A Zeiss Stemi 2000-C microscope equipped with a U-Photo photographic system was used, and AxionVision LE software was used for image acquisition.

Germination was tested with four replicates of 50 seeds per treatment. The seeds were placed in plastic boxes containing sand moistened with PEG solutions to simulate water stress, or $\mathrm{KCl}$ solutions to simulate salt stress. The volume of solution used corresponded to $100 \%$ of the retention capacity of the substrate. Gerbox containers were kept in a germination chamber at $25^{\circ} \mathrm{C}$ for 7 days (Brasil, 2009). Evaluations were performed daily, and seedlings with a length greater than or equal to $10 \mathrm{~mm}$ were considered germinated. From this data, germination curves were fitted according to time using the Boltzman sigmoid model, and the time to reach $50 \%$ germination $(\mathrm{t} 50 \%)$ and germination speed (GS $=1 / \mathrm{t} 50 \%)$ were estimated. The values of GS were subjected to regression analysis according to osmotic potential, and from the $\mathrm{x}$-axis intercept for each of the regressions, the base water potential $(\Psi b)$ was estimated (Singh et al., 2017).

Growth analysis was made in four replications of 10 seedlings, obtained seven days after sowing at $25^{\circ} \mathrm{C}$ in BOD. The seedlings were evaluated for root and hypocotyl length using a digital caliper. The fresh and dry matter of seedlings, obtained after drying in a forced air circulation drying oven at $70^{\circ} \mathrm{C}$ for 72 hours, were determined. From the data on fresh and dry matter, the water content of the seedlings was calculated by the equation: $\mathrm{WC}=((\mathrm{fw}-\mathrm{dw}) /$ $\mathrm{dw}) \times 100$, where $\mathrm{WC}$ is the water content of the seedlings; fw is the fresh weight of the seedlings; and dw is the dry weight of the seedlings.

Intracellular potassium content $\left(\mathrm{K}^{+}\right)$was determined in four replicates of 50 seeds that were placed to germinate between three sheets of paper towel moistened with $10 \mathrm{~mL}$ of solution at the different potentials as described above, induced by $\mathrm{KCl}$, until radicle emergence. After that, the seeds were dried in a forced air circulation drying oven at $70{ }^{\circ} \mathrm{C}$ for $72 \mathrm{~h}$ and macerated to fine powder. Two $1 \mathrm{-g}$ samples were taken from each treatment for determination of $\mathrm{K}^{+}$quantification. Then, nitric-perchloric digestion was carried out, followed by flame photometric.

Antioxidative enzyme activities were analyzed in four replicates of 50 seeds per treatment, which were arranged in plastic boxes between three sheets of paper towel and moistened with $10 \mathrm{~mL}$ of the PEG or $\mathrm{KCl}$ solutions at the different osmotic potentials. The samples were kept in BOD, under a constant temperature of $25{ }^{\circ} \mathrm{C}$, until the seventh day after sowing. The normal seedlings were collected, packed in aluminum foil bags, frozen in liquid nitrogen, and subsequently lyophilized. The crude enzyme extract for determination of enzyme activity was obtained by maceration of $50 \mathrm{mg}$ of plant tissue with liquid nitrogen, with the addition of $4.0 \mathrm{~mL}$ of extraction buffer containing $0.1 \mathrm{mM}$ potassium phosphate buffer at $\mathrm{pH} 6.8,0.1 \mathrm{mM}$ ethylenediamine tetraacetic acid (EDTA), $1 \%(\mathrm{w} / \mathrm{v})$ polyvinylpolypyrrolidone (PVPP), and $1 \mathrm{mM}$ phenylmethylsulfonyl fluoride (PMSF) (Peixoto et al., 1999). The contents were centrifuged at $12,000 \mathrm{x}$ g for 15 minutes at $4{ }^{\circ} \mathrm{C}$, and the supernatant was added to the reaction medium for evaluation of enzyme activity. Protein content was determined according to the methodology described by Bradford (1976) using BSA as a standard and $100 \mu \mathrm{l}$ of the extract. Reading was performed at the wavelength of $595 \mathrm{~nm}$.

Superoxide dismutase (SOD, EC 1.15.1.1) activity was obtained by the reaction of $100 \mu \mathrm{L}$ of crude enzyme extract added to $2.90 \mathrm{~mL}$ of reaction medium containing $50 \mathrm{mM}$ potassium phosphate buffer at $\mathrm{pH} 7.8,13 \mathrm{mM}$ methionine, $0.1 \mathrm{mM}$ EDTA, $2 \mu \mathrm{M}$ riboflavin, and $75 \mu \mathrm{M}$ p-nitro blue tetrazolium (NBT) (Del Longo et al., 1993). The reaction was carried out in a reaction chamber with $15 \mathrm{~W}$ fluorescent lamp lighting, and the samples were kept under constant light for three minutes. After the light was interrupted, reading was carried out at $560 \mathrm{~nm}$. Control samples was obtained under the same conditions, but without the presence of light (Giannopolitis; Ries, 1977). A unit of SOD was defined as the amount of enzyme capable of $50 \%$ inhibition of NBT photoreduction.

Catalase (CAT, EC 1.11.1.6) activity was obtained by reacting $100 \mu \mathrm{L}$ of the crude enzyme extract added to $2.9 \mathrm{~mL}$ of reaction medium containing $50 \mathrm{mM}$ potassium phosphate buffer at $\mathrm{pH} 7.0$ and $12.5 \mathrm{mM} \mathrm{H}_{2} \mathrm{O}_{2}$ (Havir; Mchale, 1987). The decrease in absorbance at $240 \mathrm{~nm}$ at $25^{\circ} \mathrm{C}$ for one minute was measured. Enzyme activity was calculated using the molar extinction coefficient of $36 \mathrm{M}^{-1} \mathrm{~cm}^{-1}$.

Peroxidase (POX, EC 1.11.1.7) activity was obtained by reacting $100 \mu \mathrm{L}$ of the extract added to $2.9 \mathrm{~mL}$ of reaction 
medium containing $25 \mathrm{mM}$ potassium phosphate buffer at pH 6.8, $20 \mathrm{mM}$ guaiacol, and $20 \mathrm{mM} \mathrm{H}_{2} \mathrm{O}_{2}$ (Kar; Mishra, 1976). The increase in absorbance at $420 \mathrm{~nm}$ at $25^{\circ} \mathrm{C}$ for one minute was measured, and enzyme activity was calculated using the molar extinction coefficient of $2.47 \mathrm{mM} \mathrm{L}^{-1} \mathrm{~cm}^{-1}$.

The experiment was conducted in a completely randomized design in a $2 \times 4+1$ factorial arrangement (two osmotic solutions, PEG 6000 and $\mathrm{KCl}$, and four osmotic potentials, $-0.2,-0.4,-0.6$, and $-0.8 \mathrm{MPa}$, plus one more control). The data were subjected to ANOVA and the means obtained in the evaluations for two salts at the different potentials were compared by the $F$ test $(p<0.05)$. The means of the treatments with control were compared by the $\mathrm{t}$ test $(\mathrm{p}<0.05)$.

\section{RESULTS AND DISCUSSION}

Figure 1 shows the seed of the crambe fruit during the imbibition process. In Figure 1A, the external appearance of the fruit is shown, which consists of the pericarp and the seed. In Figure 1B, the seed without the pericarp after exposure to 12 hours of imbibition is shown. According to Donadon et al. (2013), the crambe seed is constituted by the tegument and embryo, which contains the embryonic axis and cotyledons and no endosperm in mature seeds. Figure 1C shows the seed at the beginning of germination; the time required for radicle emergence depends on the treatments (Figure 2).

Water uptake by crambe seeds was affected by two factors: osmotic potential and the type of stress to which the seeds were subjected. The speed of water uptake decreased with reduction in osmotic potential (Figure 2).

When the seeds were soaked in distilled water, i.e., in the control treatment, radicle emergence took 42 hours. When the seeds were subjected to salt stress with $\mathrm{KCl}$, radicle emergence occurred at $60,72,84$, and 108 hours at the potentials of $-0.2,-0.4,-0.6$, and $-0.8 \mathrm{MPa}$, respectively. In the PEG 6000 treatments, under water stress, radicle emergence occurred at 84,168 , and 168 hours at the -0.2 ,
-0.4, and -0.6 MPa potentials, respectively; at the potential of $-0.8 \mathrm{MPa}$, there was no radicle emergence after 168 hours of imbibition. The seeds reached about $60 \%$ water content at the radicle emergence stage in all treatments, except at the potentials of -0.6 and $-0.8 \mathrm{MPa}$ induced by PEG 6000 , which reached approximately $54 \%$ and $47 \%$, respectively. Seeds absorbed water faster (K, Table 1) and reached a higher water content when they were under salt stress, compared to water stress at the same potentials (Figure 2).

Crambe seeds were more tolerant to salt stress than to water stress, with a higher percentage of germination at all osmotic potentials induced by $\mathrm{KCl}$ compared to the same potentials induced by PEG 6000 (Figure 3A). The reduction in germination was more intense with reduction in osmotic potential, i.e., with the increase in the level of stress (Figure 3A). The decrease in germination was evident from the $-0.2 \mathrm{MPa}$ potential in water stress and from $-0.4 \mathrm{MPa}$ in salt stress. At the potential of $-0.8 \mathrm{MPa}$ induced by PEG 6000 , seed germination was not observed, whereas at the same potential, but under salt stress induced by $\mathrm{KCl}$, seed germination was approximately $50 \%$. Under water stress, there was an increase in the $550 \%$ with the increase in stress levels, indicating delay in germination with the decrease in osmotic potential. However, under salt stress, delay in the germination was observed only at the $-0.8 \mathrm{MPa}$ potential (Figure 3B). Germination speed reduced with the decrease in osmotic potential of the medium, and this was also more intense for the seeds subjected to water stress (Figure 3C).

As with the decrease in germination, a reduction in seed germination speed was observed with reduction in the osmotic potential of the seeds (Figure 4A). In addition, the base water potential $(\mathrm{Ib})$, i.e., the theoretical minimum osmotic potential for seed germination (Figure 4), was estimated. When subjected to PEG-induced water stress, the equation $\mathrm{GS}=0.3210 \Psi_{\mathrm{o}}+0.2857\left(\mathrm{R}^{2}=0.86\right) \mathrm{was}$ estimated, with an estimated value for $\Psi \mathrm{b}$ of $-0.89 \mathrm{MPa}$, whereas for salt stress induced by $\mathrm{KCl}$, the equation $\mathrm{GS}$ $=0.1406 \Psi_{0}+0.3231\left(\mathrm{R}^{2}=0.99\right)$ was estimated, with an estimated value for $\Psi \mathrm{b}$ of $-2.3 \mathrm{MPa}$.
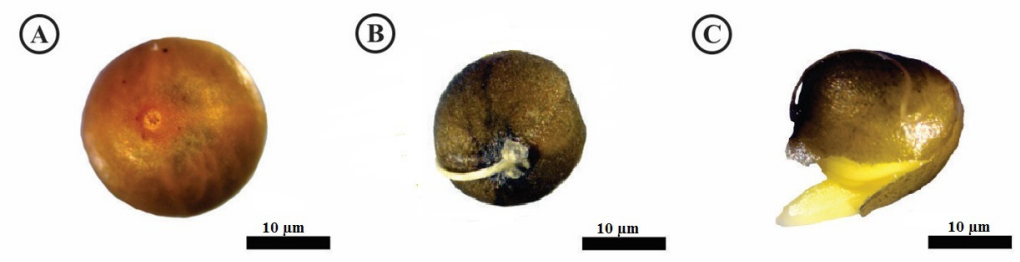

Figure 1: Seed of crambe fruit during the imbibition process. Seed before imbibition (A); seed without the pericarp, after 12 hours of imbibition (B); seed at the beginning of germination, exhibiting radicle protrusion (C). 
(A)

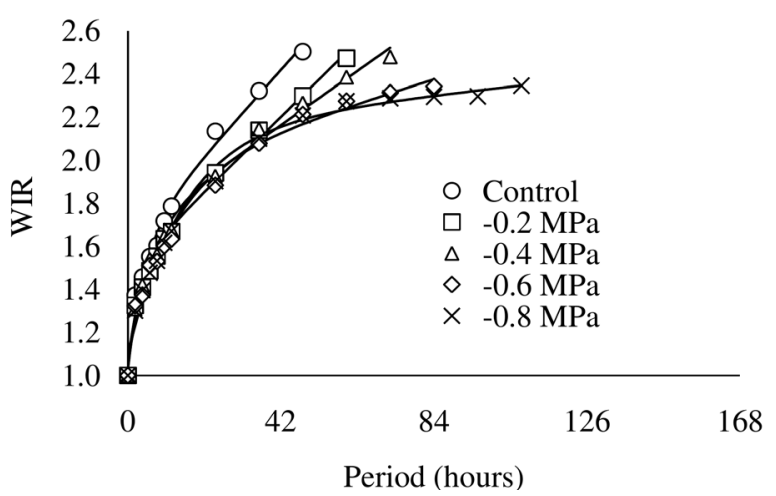

(B)

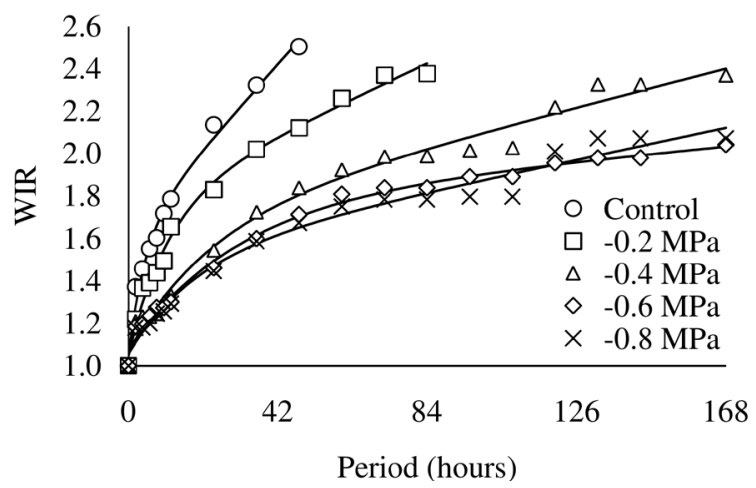

Figure 2: Rate of weight increase (WIR) of Crambe abyssinica seeds under different osmotic potentials induced by $\mathrm{KCl}(\mathrm{A})$ or PEG 6000 (B).

Table 1: Estimated regression coefficients for water uptake curves of Crambe abyssinica seeds under different osmotic potentials induced by PEG 6000 or $\mathrm{KCl}$.

\begin{tabular}{cccccc}
\hline Solution & $\begin{array}{c}\text { Osmotic } \\
\text { Potential (MPa) }\end{array}$ & $\mathrm{a}$ & $\mathrm{b}$ & $\mathrm{W}_{0}{ }^{\prime}$ & $\mathrm{k}$ \\
\hline Control & 0.0 & $1.753 \pm 0.084$ & $0.016 \pm 0.003$ & $1.062 \pm 0.004$ & $0.155 \pm 0.015$ \\
\hline \multirow{3}{*}{ PEG 6000 } & -0.2 & $1.837 \pm 0.209$ & $0.007 \pm 0.003$ & $1.044 \pm 0.018$ & $0.067 \pm 0.019$ \\
& -0.4 & $1.684 \pm 0.154$ & $0.004 \pm 0.002$ & $1.065 \pm 0.009$ & $0.044 \pm 0.011$ \\
& -0.6 & $1.727 \pm 0.112$ & $0.002 \pm 0.001$ & $1.064 \pm 0.018$ & $0.038 \pm 0.005$ \\
& -0.8 & $2.175 \pm 0.288$ & $-0.002 \pm 0.003$ & $1.071 \pm 0.014$ & $0.023 \pm 0.005$ \\
\hline \multirow{3}{*}{$\mathrm{KCl}$} & -0.2 & $1.479 \pm 0.049$ & $0.017 \pm 0.001$ & $1.018 \pm 0.014$ & $0.213 \pm 0.007$ \\
& -0.4 & $1.673 \pm 0.125$ & $0.013 \pm 0.003$ & $1.045 \pm 0.018$ & $0.168 \pm 0.053$ \\
& -0.6 & $1.918 \pm 0.129$ & $0.005 \pm 0.002$ & $1.091 \pm 0.009$ & $0.086 \pm 0.015$ \\
& -0.8 & $2.143 \pm 0.108$ & $0.002 \pm 0.001$ & $1.095 \pm 0.006$ & $0.066 \pm 0.007$ \\
\hline
\end{tabular}

As with seed germination, seedling growth was impaired under stress conditions. At all levels of stress, the growth and water content of salt-stressed seedlings were higher compared to water-stress seedlings at the same osmotic potentials (Figure 5).

Compared to the control, root and hypocotyl length were affected by water stress from the -0.4 MPa potential on, but salt stress only impaired root length from the potential of $-0.6 \mathrm{MPa}$ on, without affecting hypocotyl length (Figure 5A-B).

There was a reduction in the fresh weight and in the water content of the seedlings with the decrease in the potential induced by PEG. However, there was no reduction in fresh matter with the decrease in water potential. There was a reduction in water content only at the potential $-0.8 \mathrm{MPa}$ when subjected to salt stress (Figure 5C-E). Interestingly, there was an increase in fresh matter at the potentials -0.2 and $-0.4 \mathrm{MPa}$ (Figure 5C), due to higher water uptake by the seedlings at these potentials (Figure 5E) when the seedlings were subjected to salt stress. It is noteworthy that the dry weight of the seedlings was not reduced by water stress or salt stress (Figure 5D).

There was a growing accumulation of $\mathrm{K}^{+}$inside the seeds with the decrease in osmotic potential induced by $\mathrm{KCl}$. At the potential of $-0.8 \mathrm{MPa}$, the seeds absorbed more than the double the $\mathrm{K}^{+}$compared to the control treatment (Figure 6). These results indicate that the seeds absorbed the $\mathrm{K}^{+}$and that influenced water uptake (Figure 2) and seed germination speed (Figure 3 ). 


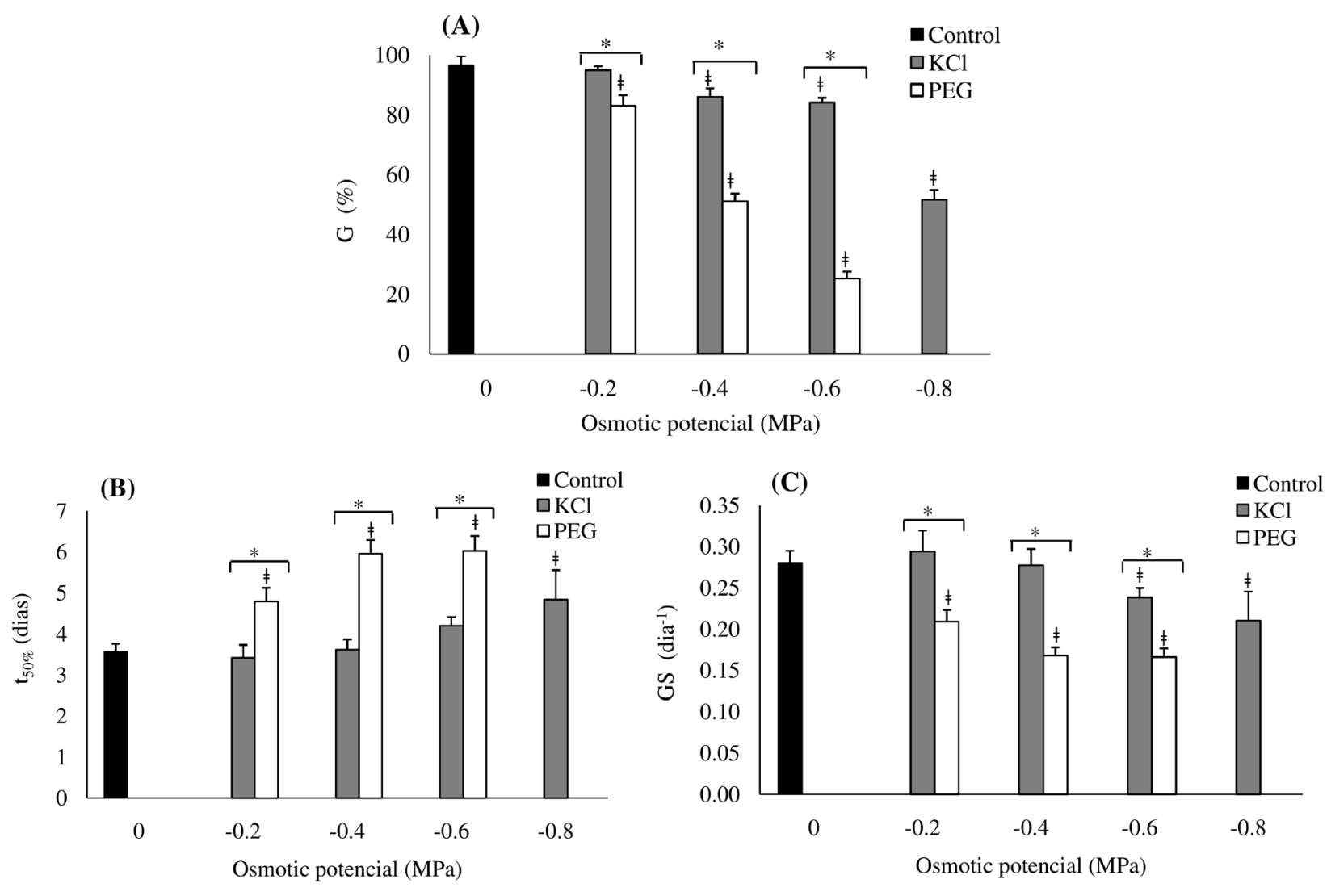

Figure 3: Germination (A); time required for $50 \%$ of seeds to germinate - $t 50 \%$ (B); and germination speed - GS (C) of Crambe abyssinica seeds under different osmotic potentials induced by PEG 6000 or KCl. The bars represent the mean of four replicates \pm the standard deviation. $\neq$ - differs from the control $(0 \mathrm{MPa})$ by the $t$ test $(p<0.05)$; * - differs statistically by the $F$ test $(p<0.05)$.
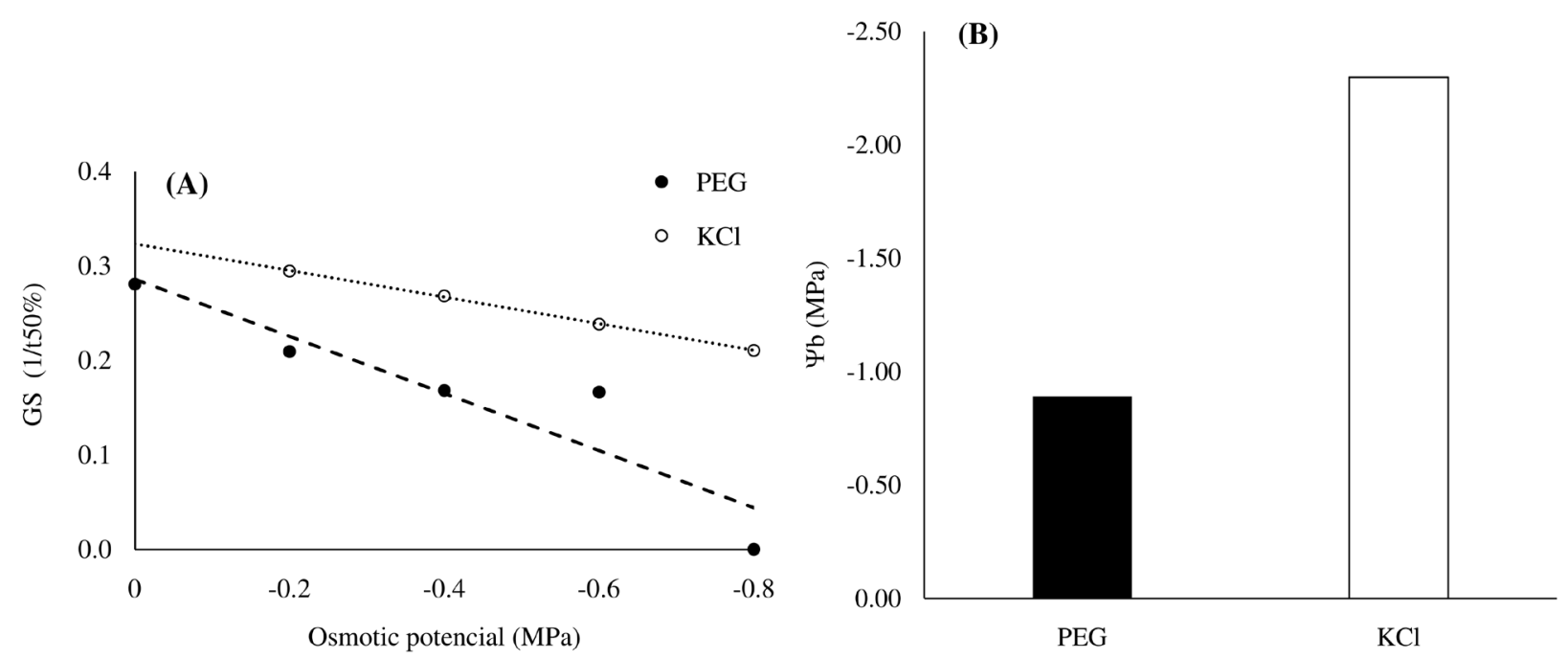

Figure 4: Germination speed - GS (1/t50\%) seven days after sowing $(A)$ and base water potential $(\Psi \mathrm{b})$ for germination (B) of Crambe abyssinica seeds under different osmotic potentials induced by PEG 6000 or KCl. 

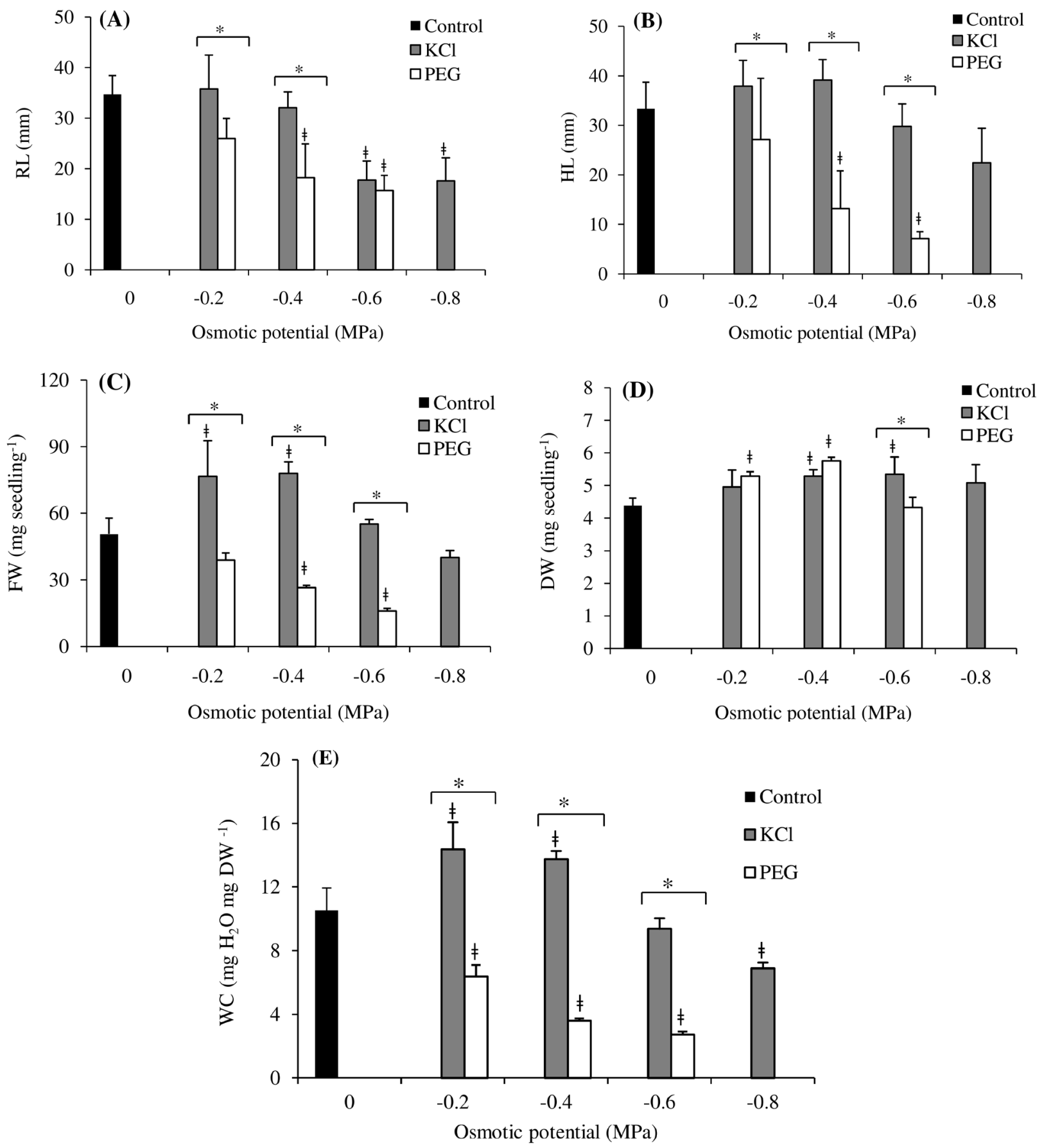

Figure 5: Growth of Crambe abyssinica seedlings under different osmotic potentials induced by PEG 6000/ $\mathrm{KCl}$. (A) root length (RL), (B) hypocotyl length $(H L),(C)$ fresh weight (FW), (D) dry weight (DW), and (E) water content (WC) of seedlings. The bars represent the mean of four replicates \pm the standard deviation. $\ddagger$ - differs from the control $(0 \mathrm{MPa})$ by the t test $(\mathrm{p}<0.05)$; * - differs statistically by the $\mathrm{F}$ test $(\mathrm{p}<0.05)$. 


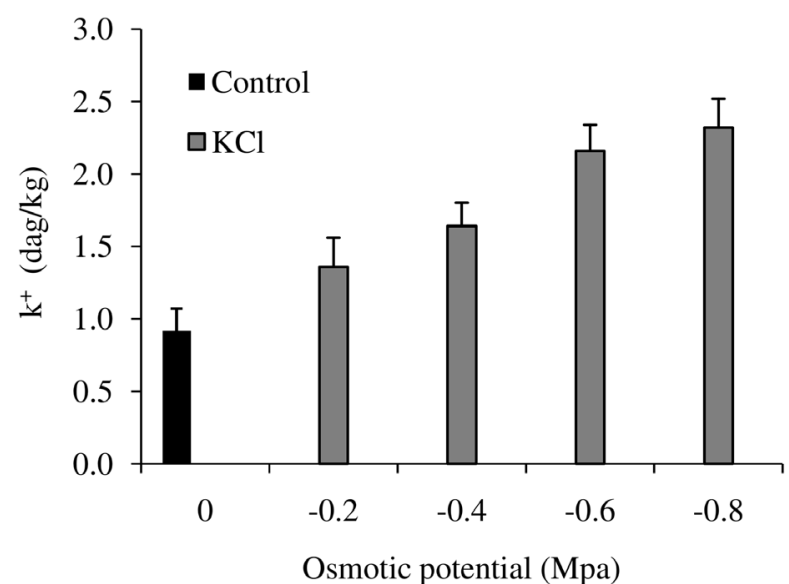

Figure 6: Intracellular potassium content $\left(\mathrm{K}^{+}\right)$in seeds of Crambe abyssinica under different osmotic potentials induced by $\mathrm{KCl}$.

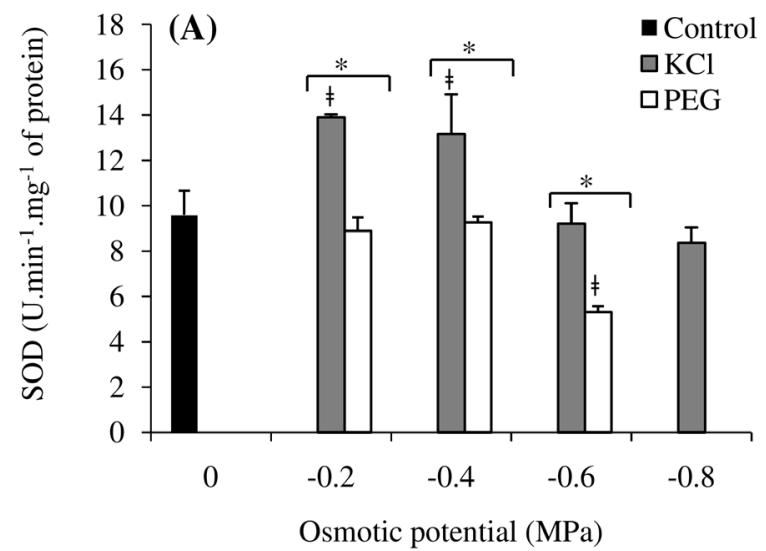

Higher activities of the SOD, CAT, and POX enzymes were observed in all treatments for the seedlings under conditions of salt stress, compared to water stress (Figure 7).

For the seeds subjected to water stress induced by PEG, the activity of the SOD enzyme did not differ from the control at the potentials of -0.2 and $-0.4 \mathrm{MPa}$, and it was lower at the potential of $-0.6 \mathrm{MPa}$ (Figure 7A). In contrast, for the seeds subjected to salt stress, there was an increase in the activity of this enzyme at the potentials of -0.2 and $-0.4 \mathrm{MPa}$ and reduction at the highest stress levels, -0.6 and $-0.8 \mathrm{MPa}$; however, it did not differ from the control treatment at these latter potentials.

In the seedlings under water stress induced by PEG, the activity of the CAT enzyme did not differ from the control (Figure 7B). However, as observed for SOD under salt stress, the CAT activity increased at the potentials
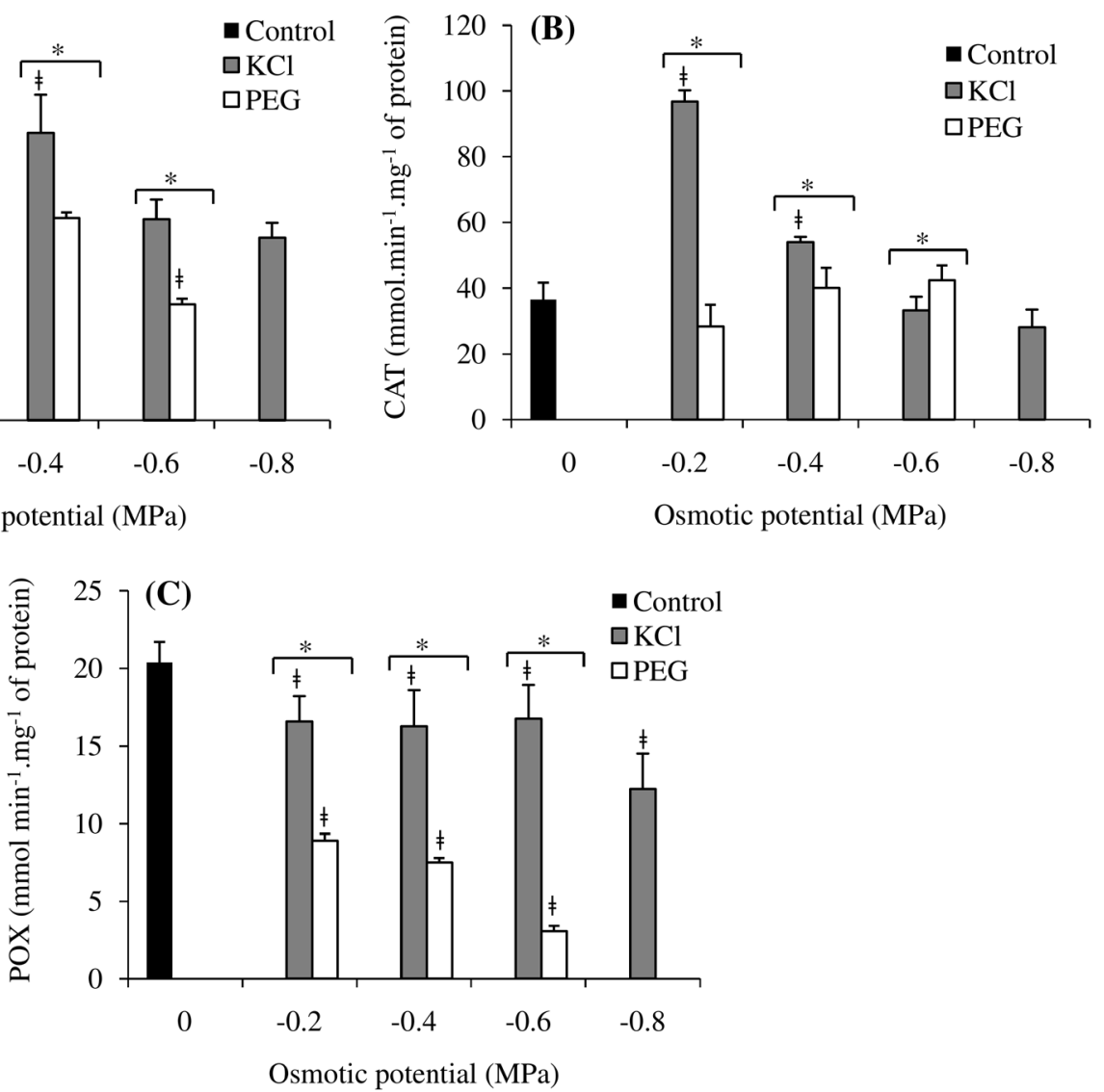

Figure 7: Activity of the antioxidative defense system enzymes in Crambe abyssinica seedlings seven days after sowing under different osmotic potentials induced by PEG 6000 or KCl. (A) SOD - Superoxide Dismutase, (B) CAT - Catalase, and (C) POX - Peroxidase. The bars represent the mean of four replicates \pm the standard deviation. $\neq$ - differs from the control $(0 \mathrm{MPa})$ by the t test $(p<0.05)$; * - differs statistically by the $\mathrm{F}$ test $(p<0.05)$. 
of -0.2 and $-0.4 \mathrm{MPa}$ but did not differ from the control treatment at the lower potentials, i.e., -0.6 and $-0.8 \mathrm{MPa}$.

There was a reduction in POX activity at all osmotic potentials compared to the control, under both water and salt stresses (Figure 7C).

According to the data obtained in the present study, the water uptake rate of crambe seeds decreased with reduction in osmotic potential (Figure 2, Table 1). Therefore, seed germination declined and $\mathrm{t} 50 \%$ (the time required for $50 \%$ of seeds to germinate) increased. GS also declined (Figure 3), especially at the lower osmotic potentials $(-0.6$ and $-0.8 \mathrm{MPa})$. For the seeds under PEG-induced water deficit at the potential of -0.8 $\mathrm{MPa}$, water content reached the lowest value, $47 \%$, and the germination process had not concluded seven days after sowing (Figure 2); the seeds remained in stage II of imbibition, as described by Bewley et al. (2013). When the seeds were soaked in distilled water and in all the salt solutions, they reached about $60 \%$ water content and there was evident radicle emergence. The lower the osmotic potential of the medium, the lower the water uptake rate by the seeds, which directly affects the speed and the percentage of germination (Bewley et al., 2013). The water uptake rate of seeds varies among species and depends on the conditions seeds are subjected to. In general, under low osmotic potentials, this rate declines. This can lead to absorption at a rate lower than necessary for germination that consequently delays or inhibits progression of the stages that culminate in germination (Bewley et al., 2013).

Salinity and water deficit cause changes in several physiological and metabolic processes in seeds (Yacoubi et al., 2013), which may compromise seed germination and seedling establishment. Water deficit decreases the speed and the percentage of seed germination (Machado et al., 2017), disturbs the activities of amylases and proteases, and increases oxidative stress, leading to a reduction in seedling biomass (Ali et al., 2017). Salinity may compromise seed germination by reducing external osmotic potential, which prevents water uptake, as occurs under water deficit conditions and/or from the toxic effects of ion absorption (Zhang et al., 2010). Both the osmotic stress and the toxic effect of salts may be responsible for inhibition and delay in seed germination and seedling establishment.

In the present study, the same osmotic potentials were used for the water deficit and salt stress treatments; however, the osmotic agents generated different responses in water uptake and seed germination (Table 1, Figure 2-3). These differences may be due to the chemical nature of the agents (Ortiz et al., 2014). PEG 6000 is a chemically inert and non-toxic solute that is not absorbed by seeds, due to its high molecular weight (Villela; Doni Filho; Sequeira, 1991). Thus, the reduction in water uptake by seeds under the water stress induced by PEG was due to the restriction in water input caused by this compound. In contrast, salt has low molecular weight and can easily penetrate and be absorbed by cells (Hadas, 1976), as can be seen in Figure 6 . However, this absorption at high concentrations may cause toxic effects and impair the germination process (Ghanad et al., 2016). This response was evident in the seeds under the lowest osmotic potentials induced by $\mathrm{KCl}$ $(-0.6$ and $-0.8 \mathrm{MPa})$; these seeds had $50 \%$ germination at the lowest potential (Figure 3 ).

The water uptake rate of the seeds was always higher in the $\mathrm{KCl}$ treatments (Figure 2, Table 1), which led to a lower $\mathrm{t} 50 \%$ and higher GS under salt stress compared to water stress (Figure 3). These results suggest that the effect of salt stress was more influenced by the ionic component than by the osmotic component. Potassium ions entered the seeds (Figure 6) and may have been compartmentalized, reducing osmotic potential within the cell and contributing to more water uptake by the seeds (Figure 2). This would explain the higher water uptake in the $\mathrm{KCl}$ treatments compared to the PEG 6000 treatments (Figure 2). Shabala (2017) has reported that retention of potassium in tissues is an essential mechanism in plant tolerance to salt stress. According to Zhang et al. (2010), absorption and compartmentalization of salts inside the seeds is a salinity tolerance mechanism since absorption of salts leads to reduction in the osmotic potential inside the cells, thus allowing greater water uptake and faster germination in environments with low osmotic potential. The results suggest that this mechanism of absorption and compartmentalization of salt is adopted by crambe seeds since the processes of water uptake (Figure 2), germination (Figure 3), and seedling growth (Figure 5) were less compromised in the $\mathrm{KCl}$ treatments than under the PEG treatments at the same potentials.

The data obtained in the present study also showed $\Psi \mathrm{b}$ of $-2.3 \mathrm{MPa}$ for salt stress and $-0.89 \mathrm{MPa}$ for water stress (Figure 4), showing greater tolerance of the seeds to salt stress induced by $\mathrm{KCl}$ than to water stress induced by PEG. The base water potential $(\Psi \mathrm{b})$ is the lowest osmotic potential at which seed germination could theoretically still be possible, and it can be used to more accurately determine the osmotic stress tolerance of a species (Singh et al., 2017).

In addition to seed germination, seedling growth under water or salt stress conditions may be impaired (Ionov et al., 2013), as appeared in the present study for 
both salt stress and water stress under the lower osmotic potentials (Figure 5). However, there was no decrease in root and hypocotyl length at the potentials of -0.2 and -0.4 $\mathrm{MPa}$ induced by $\mathrm{KCl}$. In addition, reduction in seedling length was more drastic under water stress than under salt stress at all osmotic potentials (Figure 5).

These results show sensitivity of crambe seeds to water deficit and moderate tolerance to salt stress, following the classification proposed by Maas and Hoffman (1977). Ionov et al. (2013) also considers crambe seeds as moderately tolerant to salinity, and Qi et al. (2018) describes that this crop can grow in saline soil and can tolerate salty irrigation water. Boiago et al. (2018) describes crambe as sensitive to water restriction conditions at different stages of its development.

The lower values of fresh matter obtained for seedlings under water stress are related to restriction in water uptake, which intensifies as osmotic potential decreases (Figure 5C). Water acts on cell growth and elongation, and it is necessary that the osmotic potential within the cell be lower than the water potential of the medium for water to enter, which leads to cell expansion and, consequently, plant organ growth (Tardieu et al., 2014). In the present study, it is evident that the more intense reduction in water content of the seedlings under water stress (Figure 5E), related to lower water uptake, led to the lower cell expansion and, therefore, reduction in size. Water deficit reduces cell expansion and affects the processes of cell division, which interferes with plant development. Under salt stress, the probable strategy of salt absorption and compartmentalization in crambe was efficient in mitigating the effects of salinity, which favored germination (Figure 3) and seedling growth (Figure 5). However, under more drastic conditions, i.e., at lower osmotic potentials, the tolerance mechanism was supplanted by the phytotoxic effects of the salt, and the viability and growth of the seedlings were reduced (Figure 3 and 5).

Plants often respond to water or salt stress conditions through an increase in production of reactive oxygen species (ROS) in several cell compartments. ROS is a term that includes molecules such as singlet oxygen, superoxide, hydrogen peroxide $\left(\mathrm{H}_{2} \mathrm{O}_{2}\right)$, and the hydroxyl radical (Noctor; Reichheld; Foyer, 2018). These molecules may react with others and cause several disturbances. The ROS, if not maintained at appropriate levels, can lead to a decrease in seed germination and vigor (Kumar et al., 2015). When ROS are perceived, a cascade of cell signaling occurs (Noctor; Reichheld; Foyer, 2018). If ROS production is excessive and affects cell homeostasis, mechanisms are activated to control production of ROS and eliminate them (Mittler et al., 2002). The enzymatic and non-enzymatic antioxidative defense system acts to control the excess of these highly reactive molecules.

Being part of the enzymatic mechanisms of the antioxidative defense complex are the SOD, CAT, and POX enzymes. SOD acts in the first line of defense, dismutating $\mathrm{O}_{2}^{-}$to $\mathrm{H}_{2} \mathrm{O}_{2}$, and the enzymes CAT and POX then convert $\mathrm{H}_{2} \mathrm{O}_{2}$ to $\mathrm{H}_{2} \mathrm{O}$ and $\mathrm{O}_{2}$, promoting cell destoxification (Mittler, 2002). Synchronized action of the enzymes responsible for the removal of ROS can give greater tolerance to the seedlings under stress conditions (Ali et al., 2017). Mittler (2002) points out that CAT and SOD are the main antioxidant enzymes against stress situations. Ali et al. (2017) associates better seedling biomass accumulation under drought stress with better ROS scavenging mechanisms.

In the present study, there was a reduction in SOD activity at the potential of $-0.6 \mathrm{MPa}$ and in CAT activity in seedlings under water stress by PEG, and this did not change at the different osmotic potentials (Figure 7). This suggests that the antioxidative defense system, which involves SOD and CAT activity, was not efficient in mitigating the effects of water stress, which caused the oxidative damages that led to reduction in germination and seedling growth with reduction in osmotic potential (Figure 3 and 5). However, when the seedlings were under salt stress, a large increase in the activity of these enzymes was observed at the potentials of -0.2 and $-0.4 \mathrm{MPa}$. Thus, the antioxidative defense mechanism, which promotes an increase in enzyme activity to avoid oxidative damage to cells (Kumar et al., 2015) by the action of SOD and CAT, was efficient in reducing the effects of ROS. It allowed high levels of germination (Figure 3 ) and seedling growth (Figure 5) at moderate levels of salt stress, i.e., at potentials of -0.2 and $-0.4 \mathrm{MPa}$. Under conditions of more drastic stress, however, the activity of antioxidative enzymes is often compromised (Greggains et al., 2000), as observed in the present study for the potentials -0.6 and $-0.8 \mathrm{MPa}$ induced by $\mathrm{KCl}$. Thus, it can be inferred that under moderate salt stress, the antioxidative defense system in the seedlings, assessed by SOD and CAT activity, which was efficient in detoxifying the ROS, is part of the strategy for crambe tolerance to this stress. Kumar et al. (2018) described an increase in SOD activity in the salt-tolerant cultivar that was not observed in the sensitive cultivar of Brassica juncea when salt stress was induced.

There was reduction in POX activity for both osmotic solutions, and the activity was significantly lower in relation to the control treatment at all osmotic potentials 
(Figure 7C). Therefore, POX activity seems not to be involved in detoxification of ROS in crambe seedlings. Kumar et al. (2018) did not find difference in POX activity of the salt-tolerant and salt-sensitive cultivar of Brassica juncea when salt stress was applied. Stevens et al. (1978) observed a decrease in POX activity in plants of 11 brassica cultivars under salt stress and concluded that there is no parallel between the antioxidant defense response and the activity of this peroxidase. These authors speculated that the activity of this enzyme seems to be more related to the hormonal regulation and lignification processes than to the mechanism of defense against salts.

In general, both water stress and salt stress reduced water uptake (Figure 2), seed germination (Figure 3), and seedling growth (Figure 5). However, the effects observed were more intense under water stress induced by PEG, showing the sensitivity of crambe seeds to water deficit during germination and seedling growth. Machado et al. (2017) also reported reduction in the percentage and speed of germination with a decrease in osmotic potential, in crambe seeds.

According to the data obtained from this study, crambe seeds showed tolerance to moderate levels of salt, since at the potentials of -0.2 and $-0.4 \mathrm{MPa}$ induced by $\mathrm{KCl}$, germination was high, at $95 \%$ and $86 \%$, respectively, and seedling growth was not impaired (Figure 3 and 5). The data suggest that under moderate salt stress, crambe tolerance mechanisms, such as the action of antioxidant defense enzymes and $\mathrm{K}^{+}$absorption and possible $\mathrm{K}^{+}$ compartmentalization, may be effective in overcoming the deleterious effects of salt. Thus, crambe can be recommended for planting in saline soils with moderate levels of salinity, i.e., in soils in which osmotic potential does not exceed -0.4 MPa.

\section{CONCLUSIONS}

Water deficit and salt stress reduce the water uptake rate and germination percentage of seeds and reduce seedling growth in crambe. Crambe seeds have higher tolerance to salt stress than to water deficit. The absorption of salt and SOD and CAT antioxidant enzyme activity are part of the tolerance mechanisms of crambe seeds to salt stress.

\section{ACKNOWLEDGMENTS}

This study was funded in part by the Coordenação de Aperfeiçoamento de Pessoal de Nível Superior - Brasil (CAPES) - Finance Code 001. The authors thank CAPES for its support.

\section{REFERENCES}

ALI, Q. et al. Assessment of drought tolerance in mung bean cultivars/lines as depicted by the activities of germination enzymes, seedling's antioxidative potential and nutrient acquisition. Archives of Agronomy and Soil Science, 63(1):1-9, 2017.

BEWLEY, J. D. et al. Seeds: Physiology of development, germination and dormancy. New York: Springer, 2013. 392p.

BLACKLOW, W. M. Mathematical description of the influence of temperature and seed quality on imbibition by seeds of corn (Zea mays L.). Crop Science, 12(5):643-646, 1972.

BOIAGO, N. P. et al. Morphophysiological and nutritional characteristics of Crambe abyssinica Hochst under hydric restriction in different phenological stages. Acta Physiologiae Plantarum, 40(99):1-6, 2018.

BRADFORD, M. M. A rapid and sensitive method for the quantitation of microgram quantities of protein utilizing the principle of protein-dye binding. Analytical Biochemistry, 72(1):248-254, 1976.

BRASIL. Ministério da Agricultura, Pecuária e Abastecimento. Regras para análise de sementes. Ministério da Agricultura, Pecuária e Abastecimento. Secretaria de Defesa Agropecuária. Brasília: Mapa/ACS, 2009. 395p.

COLTRO-RONCATO, S. et al. Nematicidal effect of Crambe abyssinica leaf extracts to Meloidogynejavaica on tomato. African Journal of Agricultural Research, 11(32):30043011, 2016.

DEL LONGO, O. T. et al. Antioxidant defenses under hyperoxygenic and hyperosmotic conditions in leaves of two lines of maize with differential sensitivity to drought. Plant \& Cell Physiology, 34(7):1023-1028, 1993.

DONADON, J. R. et al. Effect of hot air drying on ultrastructure of crambe seeds. Drying Technology, 31(3):269-276, 2013.

FALASCA, S. L. et al. Crambe abyssinica: An almost unknown crop with a promissory future to produce biodiesel in Argentina. International Journal of Hydrogen Energy, 35(1):5808-5812, 2010.

GHANAD, M. et al. The effects of $\mathrm{NaCl}, \mathrm{KCl}$ and $\mathrm{MgCl}_{2}$ on the germination of Brassica rapa var. parachinensis seed. International Journal of Biological Research, 4(1):5255, 2016.

GIANNOPOLITIS, C. N.; RIES, S. K. Superoxide dismutases. Plant Physiology, 59(1):315-318, 1977. 
GOES, R. H. T. B. et al. Intake, digestibility, performance and carcass characteristics of ewes fed crambe replacing soybean meal in the diet. Acta Scientiarum Agronomy, 40(37171):1-8, 2018.

GOMES, M. P.; GARCIA, Q. S. Reactive oxygen species and seed germination. Biologia, 68(3): 351-357, 2013.

GREGGAINS, V. et al. Metabolism-induced free radical activity does not contribute significantly to loss of viability in moist-stored recalcitrant seeds of contrasting species. New Phytologist, 148(1):267-276, 2000.

HADAS, A. Water uptake and germination of leguminous seeds under changing external water potential in osmotic solution. Journal of Experimental Botany, 27(1):480-489, 1976.

HAVIR, E. A.; MCHALE, N. A. Biochemical and developmental characterization of multiple forms of catalase in tobacco leaves. Plant Physiology, 84(1):450-455, 1987.

IONOV, M. et al. Growth, development and yield of Crambe abyssinica under saline irrigation in the greenhouse. Journal of Agronomy and Crop Science, 199(2013):331339, 2013.

JABEEN, N.; AHMAD, R. The activity of antioxidant enzymes in response to salt stress in safflower (Carthamus tinctorius L.) and sunflower (Helianthus annuus L.) seedlings raised from seed treated with chitosan. Journal of the Science of Food and Agriculture, 93(1):1699-1705, 2013.

KAR, M.; MISHRA, D. Catalase, peroxidase, and polyphenoloxidase activities during rice leaf senescence. Plant Physiology, 57(1):315-319, 1976.

KUMAR, M. et al. Differential behavior of the antioxidant system in response to salinity induced oxidative stress in salt-tolerant and salt-sensitive cultivars of Brassica juncea L. Biocatalysis and Agricultural Biotechnology, 13(1):1219, 2018.

KUMAR, S. P. J. et al. Seed birth to death: Dual functions of reactive oxygen species in seed physiology. Annals of Botany, 116(4):663-668, 2015.

MAAS, E. V.; HOFFMAN, G. J. Crop salt tolerance - Current assessment. Journal of the Irrigation and Drainage Division, American Society of Civil Engineers, 103(2):115134,1977

MACHADO, F. H. B. et al. Physiological quality of seed and seedling performance of crambe genotypes under water stress. Revista Brasileira de Engenharia Agrícola e Ambiental, 21(3):175-179, 2017.
MITTLER, R. Oxidative stress, antioxidants and stress tolerance. Trends in Plant Science, 7(9): 405-410, 2002.

NOCTOR, G.; REICHHELDB, J.; FOYER, C. H. ROS-related redox regulation and signaling in plants. Seminars in Cell \& Developmental Biology, 80(2018):3-12, 2018.

OLIVEIRA, A. B.; GOMES-FILHO, E.; ENÉIAS-FILHO, J. O problema da salinidade na agricultura e as adaptações das plantas ao estresse salino. Enciclopédia Biosfera, 6(11):1-16, 2010.

ORTIZ, T. A. et al. Water and salt stress in germinating seeds of pitaya genotypes (Hylocereus spp.). African Journal of Agricultural Research, 9(50):3610-3619, 2014.

PEIXOTO, P. H. P. et al. Aluminum effects on lipid peroxidation and on activities of enzymes of oxidative metabolism in sorghum. Revista Brasileira de Fisiologia Vegetal, 11(3):137-143, 1999.

PITOL, C.; BROCH, L. D.; ROSCOE, R. Tecnologia e produção: Crambe 2010. Maracaju: Fundação MS, 2010. 60p.

PIVETTA, L. G. et al. Germination and initial growth of crambe (Crambe abyssinica Hochst.) under saline conditions. Australian Journal of Crop Science, 10(12):1614-1617, 2016.

QI, W. et al. Genetically engineering Crambe abyssinica: A potentially high-value oil crop for salt land improvement. Land Degradation \& Development, 29(4):1096-1106, 2018.

RENGASAMY, P. Soil processes affecting crop production in salt-affected soils. Functional Plant Biology, 37(7): 613620, 2010.

SALISBURY, F. B.; ROSS, C. W. Plant physiology. Belmont: Wadsworth Publishing Company, 1992. 682p.

SHABALA, S. Signalling by potassium: Another second messenger to add to the list? Journal of Experimental Botany, 68(15):4003-4007, 2017.

SINGH, B. et al. Developing a screening tool for osmotic stress tolerance classification of rice cultivars based on in vitro seed germination. Crop Science, 57(1):387-394, 2017.

STEVENS, H. C. et al. Peroxidase activity as a screening parameter for salt stress in Brassica species. Phytochemistry, 17(1):1521-1525, 1978.

TARDIEU, F. et al. Genetic and physiological controls of growth under water deficit. Plant Physiology, 164(4):1628-1635, 2014. 
TAVARES, G. R. et al. Assessment of ultrasound-assisted extraction of crambe seed oil for biodiesel synthesis by in situ interesterification. Renewable Energy, 111(1):659-665, 2017.

VILLELA, F. A.; DONI FILHO, L.; SEQUEIRA, E. L. Tabela de potencial osmótico em função da concentração de polietileno glicol 6000 e da temperatura. Pesquisa Agropecuária Brasileira, 26(11/12):1957-1968, 1991.
YACOUBI, R. et al. Proteomic analysis of the enhancement of seed vigour in osmoprimed alfalfa seeds germinated under salinity stress. Seed Science Research, 23(2):99110, 2013.

ZHANG, $\mathrm{H}$. et al. The effects of salinity and osmotic stress on barley germination rate: sodium as an osmotic regulator. Annals of Botany, 106(6):1027-1035, 2010. 